A N N A L E S

UNIVERSITATIS MARIAE CURIE-SKŁODOWSKA

LUBLIN - POLONIA

VOL. LXII, 2

SECTIO G

2015

ANNA KATARZYNA PASTERNAK

\title{
Zróżnicowanie tytułu ubezpieczenia zatrudnionych członków rodziny
}

The Diversity of Employment Insurance Family Members

\section{UWAGI OGÓLNE}

Ogólna zasada równości obywateli wobec prawa została wyrażona w art. 32 Konstytucji $\mathrm{RP}^{1}$. Z tą generalną zasadą wiąże się również zakaz dyskryminacji w życiu politycznym, społecznym lub gospodarczym z jakiejkolwiek przyczyny². Niemniej w poszczególnych aktach prawnych znajdują się przepisy, które doprecyzowują tę generalną zasadę. W konsekwencji w Kodeksie pracy znajduje się rozdział IIa zatytułowany „Równe traktowanie w zatrudnieniu”. Zasada równego traktowania odnosi się także do zabezpieczenia społecznego obywateli i jest przewidziana w art. 67 ust. 1 i 2 w zw. z art. 32 ust. 1 Konstytucji RP. Zgodnie z treścią tego artykułu każdy obywatel ma prawo do zabezpieczenia społecznego w razie niezdolności do pracy ze względu na chorobę, inwalidztwo, po osiągnięciu wieku emerytalnego oraz w sytuacji pozostawania bez pracy nie z własnej woli i nie mając innych środków utrzymania. Zasada równości jest głównym elementem systemu zabezpieczenia społecznego. Ustawa o systemie ubezpieczeń społecznych ${ }^{3}$

1 Przepis ten stanowi: „Wszyscy są wobec prawa równi. Wszyscy mają prawo do równego traktowania przez władze publiczne” (ust. 1); „Nikt nie może być dyskryminowany w życiu politycznym, społecznym lub gospodarczym z jakiejkolwiek przyczyny" (ust. 2).

2 Podzielam pogląd wyrażony przez Barbarę de Ankerburg-Wagner w referacie „Z problematyki równości w ubezpieczeniach społecznych", wygłoszonym podczas XIX Zjazdu Katedr i Zakładów Prawa Pracy i Ubezpieczeń Społecznych w dniach 15-17 maja 2013 roku w Poznaniu, że „równość i niedyskryminacja nie są prostymi synonimami, co wykluczałoby zasadność traktowania ich jako zamienników znaczeniowych” oraz że ,równe traktowanie nie zawsze znaczy traktowanie niedyskryminujące; traktowanie nierówne nie zawsze jest dyskryminujące".

3 Ustawa z dnia 13 października 1998 roku o systemie ubezpieczeń społecznych (t.j. Dz.U. z 2015 roku, poz. 121), dalej jako: ustawa systemowa lub ustawa. 
w art. 2a wyraża podstawową zasadę ubezpieczeń społecznych, jaką jest zasada równego traktowania ubezpieczonych.

\section{PODMIOTY UBEZPIECZENIA SPOŁECZNEGO}

Zakres podmiotowy ubezpieczenia społecznego z biegiem lat ulegał rozszerzeniu. Początkowo swoim zasięgiem obejmował tylko pracowników, następnie kolejno podmiotami ubezpieczenia stawały się osoby ,żyjące z pracy”. Poszerzania zakresu podmiotowego dokonywano przez uznanie danej grupy za pracowników albo przez objęcie odrębną ustawą określonej grupy zawodowej ${ }^{4}$. W wyniku zachodzących zmian ubezpieczenia społeczne stawały się coraz bardziej powszechne. Przed 1999 rokiem ubezpieczenia społeczne poszczególnych grup zawodowych były regulowane odrębnymi ustawami. Dopiero wejście w życie ustawy systemowej spowodowało ujednolicenie systemu prawnego w tym zakresie.

Obecnie ubezpieczenie społeczne obejmuje ubezpieczenie od następujących ryzyk: emerytalnego, rentowego, chorobowego i wypadkowego - stanowi o tym art. 1 ustawy systemowej ${ }^{5}$. Ustawa ta objęla ubezpieczeniem społecznym ubezpieczonych ${ }^{6} \mathrm{z}$ tytułu zarobkowego zatrudnienia lub innej zarobkowej działalności. Podzielam pogląd wyrażony przez J. Jończyka, który uważa, iż ,stwierdzenie, że tytułem ubezpieczeń społecznych jest zatrudnienie lub inna zarobkowa działalność zawiera skrót myślowy i wymaga wyjaśnienia, gdyż wiąże się to z tradycją ubezpieczeń społecznych, jednak obecnie obowiązkowym ubezpieczeniom podlega się również z tytułów, które mają luźny związek z zatrudnieniem"”.

Powszechność nie oznacza jednak jednolitości. W ustawie systemowej istnieją różne wyjątki i odrębności od zasady powszechności ubezpieczeń społecznych ${ }^{8}$.

4 I. Jędrasik-Jankowska, Geneza, rozwój i stan ubezpieczenia społecznego w Polsce, [w:] Ubezpieczenia społeczne w procesie zmian 80 lat Zaktadu Ubezpieczeń Społecznych, pod red. K.W. Frieske, E. Przychodaj, Warszawa 2014, s. 55-56.

5 P. Kostrzewa, [w:] E. Dziubińska-Lechnio [et al.], Ubezpieczenia społeczne, Warszawa 2014, s. 24.

6 Ustawa systemowa jest rozbudowanym aktem prawnym definiującym na swoje potrzeby niejednokrotnie także na nowo pojęcia występujące wcześniej w polskim systemie prawnym. Podstawowym pojęciem tej ustawy jest „ubezpieczony”, przez którego ustawodawca rozumie osoby fizyczne podlegające choć jednemu z czterech typów ubezpieczeń (emerytalnemu, rentowemu, chorobowemu lub wypadkowemu). Podstawą wyodrębnienia katalogu podmiotów podlegających obowiązkowi ubezpieczenia jest tytuł ubezpieczenia, czyli kryterium źródeł dochodu. Katalog ten obejmuje pracowników, członków rolniczych spółdzielni produkcyjnych i spółdzielni kółek rolniczych, osoby prowadzące pozarolniczą działalność i ich współpracowników, także osoby wykonujące pracę nakładczą i pracę na podstawie umowy o świadczenie usług, do której zgodnie z kodeksem cywilnym stosuje się przepisy dotyczące zlecenia ich współpracowników. W związku z powyższym zarówno pracownik, jak i osoba współpracująca jest ubezpieczonym.

7 J. Jończyk, Prawo zabezpieczenia społecznego, wyd. 3 uaktualnione, Kraków 2006, s. 92.

8 Ibidem, s. 89. 
Art. 5 ustawy systemowej zawiera dwa generalne wyłączenia. Pierwsze dotyczy rolników oraz obywateli obcych państw, jeżeli ich pobyt na terenie RP nie ma charakteru stałego lub są zatrudnieni w obcych przedstawicielstwach dyplomatycznych, urzędach konsularnych, misjach, misjach specjalnych lub instytucjach międzynarodowych, chyba że umowy międzynarodowe stanowią inaczej. Nie podlegają zasadzie powszechności ubezpieczeń społecznych prokuratorzy - ich wyłączenie przewiduje art. 6 ustawy systemowej. Drugą grupę stanowią sędziowie.

\section{TYTUŁ UBEZPIECZENIA}

Art. 6 ust. 1 i 2 ustawy systemowej zawiera ustawowy katalog tytułów stanowiących obowiązek ubezpieczenia społecznego. Nie narusza on zasady równego traktowania ubezpieczonych wyrażonej w art. 2a ustawy systemowej. Teza ta jest potwierdzona przez komentatorów, którzy uważają, że równe traktowanie ubezpieczonych nie oznacza ,jednakowości” stosunków ubezpieczenia społecznego wszystkich ubezpieczonych ${ }^{9}$. Powyższy pogląd jest zgodny z bogatym orzecznictwem Sądu Najwyższego, który w jednym z postanowień stwierdza: „Zasady nabywania prawa do świadczeń przez ubezpieczonych będących pracownikami mogą być ukształtowane inaczej niż ubezpieczonych z innych tytułów, w tym z tytułu zatrudnienia na podstawie umowy o pracę nakładczą" ${ }^{10}$. Zacytowany pogląd, występujący w doktrynie oraz w orzecznictwie Sądu Najwyższego, został potwierdzony przez Trybunał Konstytucyjny, który stwierdził: „[...] tytuł ubezpieczenia jest jednym z usprawiedliwionych kryteriów dyferencjacji sytuacji ubezpieczonych, akceptowanym zarówno przez doktrynę, jak i orzecznictwo" ". Bogate orzecznictwo między innymi Trybunału Konstytucyjnego sprawiło, że obecnie powyższe zagadnienie nie stanowi zbyt wielu problemów prawnych. Niemniej powstaje pytanie, czy tytuł ubezpieczenia stanowi właściwą podstawę dyferencjacji zatrudnionych członków rodziny i czy jest dopuszczalny.

\section{PRACOWNICY - PODSTAWOWA GRUPA PODLEGAJĄCA UBEZPIECZENIOM SPOŁECZNYM}

Podstawową i najbardziej powszechną grupą osób podlegających ubezpieczeniom społecznym są pracownicy, co ma swoje podłoże historyczne, ponieważ to właśnie ta grupa na początku stanowiła zakres podmiotowy ubezpieczenia społecznego.

9 P. Kostrzewa, Komentarz do art. 2(a) ustawy o systemie ubezpieczeń społecznych, System Informacji Prawnej LEX 2014 (stan prawny: 01.01.2014).

10 Postanowienie Sądu Najwyższego z dnia 8 lutego 2006 roku, III UZP 3/05, LEX nr 177435.

11 Wyrok Trybunału Konstytucyjnego z dnia 12 września 2000 roku, K 1/00, OTK 2000, poz. 185. 
Ustawa systemowa na swoje potrzeby zdefiniowała pojęcie pracownika, które jest odmienne od legalnej definicji znajdującej się w art. 2 k.p., zgodnie z którą pracownikiem jest osoba zatrudniona na podstawie umowy o pracę, powołania, wyboru, mianowania lub spółdzielczej umowy o pracę. Natomiast zgodnie z treścią art. 8 ust. 2a ustawy o systemie ubezpieczeń społecznych pracownikiem jest osoba wykonująca pracę na podstawie umowy agencyjnej, umowy zlecenia lub innej umowy o świadczenie usług, do której zgodnie z kodeksem cywilnym stosuje się przepisy dotyczące zlecenia albo umowy o dzieło, jeżeli umowę taką zawarła z pracodawcą, z którym pozostaje w stosunku pracy lub jeżeli w ramach takiej umowy wykonuje pracę na rzecz pracodawcy, z którym pozostaje w stosunku pracy. Ustawa systemowa przewiduje wyjątek od tej ogólnej definicji pracownika, bowiem jeżeli pracownik spełnia kryteria dla osoby współpracującej, to ma on status osoby współpracującej, a nie jest traktowany jak pracownik, chyba że jest to osoba zatrudniona $\mathrm{w}$ celu przygotowania zawodowego ${ }^{12}$.

\section{DEFINICJA OSOBY WSPÓŁPRACUJĄCEJ}

Ustawa systemowa w art. 6. ust. 1 i 2 oprócz pracowników wymienia również osoby prowadzące działalność gospodarczą oraz osoby z nimi współpracujące. Definicja osoby współpracującej jest zawarta w art. 8 pkt 11 ustawy systemowej, zgodnie z którą za osobę współpracującą z osobami prowadzącymi pozarolniczą działalność gospodarczą oraz zleceniobiorcami, o których mowa w art. 6 ust. 1 pkt 4 i 5 ustawy systemowej, uważa się małżonka, dzieci własne, dzieci drugiego małżonka i dzieci przysposobione, rodziców, macochę i ojczyma oraz osoby przysposabiające, jeżeli pozostają z nimi we wspólnym gospodarstwie domowym i współpracują przy prowadzeniu tej działalności lub wykonywaniu umowy agencyjnej lub umowy zlecenia; nie dotyczy to osób, z którymi została zawarta umowa o pracę w celu przygotowania zawodowego. Ustawodawca nie zdefiniował jednak samego pojęcia „osoba współpracująca”. Co więcej, w doktrynie od wielu lat toczy się dyskusja dotycząca definicji osoby współpracującej oraz współpracy przy prowadzeniu działalności gospodarczej. Z. Myszka na podstawie analizy orzecznictwa Sądu Najwyższego stwierdził: „Stosunek pracy nie mieści się w pojęciu współpracy przy prowadzeniu działalności gospodarczej”. Uważa on, że jest tak, ponieważ współpraca przy prowadzeniu działalności gospodarczej oznacza współudział w prowadzeniu tej działalności, włączając udział w zysku ${ }^{13}$. Zgadzam się z prezentowanym poglądem, ponieważ inny zakres pojęciowy ma stosunek pracy, a inny współpraca. W języku polskim słowo „współpraca” oznacza 'wykonywać pracę wspólnie z kimś'. Wielokrotnie Sąd Najwyższy zajmował

12 P. Kostrzewa, [w:] E. Dziubińska-Lechnio [et al.], op. cit., s. 27.

13 M. Skąpski, Zagadnienia stosunku pracy między członkami rodziny, Warszawa 2000, s. 202. 
się ustaleniem zakresu treściowego tego pojęcia, stwierdzając: „Za współpracę przy prowadzeniu działalności gospodarczej powodującą obowiązek ubezpieczenia emerytalnego i rentowego należy uznać taką pomoc udzieloną przedsiębiorcy przez jego małżonka, która ma charakter stały i bez której stanowiące majątek wspólny małżonków dochody z tej działalności nie osiągnęłyby takiego pułapu" ${ }^{14}$. W związku z powyższym pojęcie współpracy przy prowadzeniu działalności gospodarczej ma szersze znaczenie pojęciowe niż stosunek pracy. Do współpracy, oprócz wykonywania pracy na podstawie umowy o pracę, zaliczamy również świadczenie usług w ramach umów cywilnoprawnych oraz pomoc występującą między małżonkami, która nie jest wykonywana na podstawie umownej, tylko wiąże się z obowiązkiem wzajemnej pomocy ${ }^{15}$.

Ustawodawca, oprócz określenia kręgu osób zaliczanych do grona osób współpracujących, wymienia jako jedną z przesłanek charakteryzujących występowanie osoby współpracującej pozostawanie jej we wspólnym gospodarstwie domowym z osobą prowadzącą pozarolniczą działalność gospodarczą. W praktyce problematyczne jest ustalenie tego faktu. Sąd Najwyższy w jednym z wyroków stwierdził:

Ocena, czy osoba „pozostaje we wspólnym gospodarstwie domowym”, zależy od okoliczności konkretnego przypadku, przy czym sam fakt wspólnego zamieszkiwania nie może tu mieć decydującego znaczenia [...]. Cechami charakterystycznymi dla prowadzenia wspólnego gospodarstwa domowego może być udział i wzajemna ścisła współpraca w załatwianiu codziennych spraw związanych z prowadzeniem domu, niezarobkowanie i pozostawanie w związku z tym na całkowitym lub częściowym utrzymaniu osoby, z którą się gospodarstwo domowe prowadzi, a wszystko to dodatkowo uzupełnione cechami stałości, które tego typu sytuację charakteryzują ${ }^{16}$.

Wyżej zaprezentowane stanowisko Sądu Najwyższego potwierdza, że w praktyce bardzo trudno jest ustalić istnienie tej okoliczności. Członkowie rodziny mogą pomagać w prowadzeniu działalności gospodarczej, jednak nie może ona spełniać przesłanek charakteryzujących stosunek pracy i cechować się stałością i powtarzalnością. Co więcej, przesłanka pozostawania we wspólnym gospodarstwie domowym będzie podlegała indywidualnej ocenie w każdej sprawie rozpatrywanej przez sąd. W związku z powyższym można stwierdzić, że dopuszczalne jest zawarcie umowy o pracę z członkiem rodziny, ale warunkiem koniecznym jest niepozostawanie we wspólnym gospodarstwie domowym. Przesłanka ta nie ma jednak zastosowania $\mathrm{w}$ sytuacji zawarcia $\mathrm{z}$ małoletnim umowy o pracę $\mathrm{w}$ celu przygotowania zawodowego. $\mathrm{W}$ takim przypadku osoba małoletnia, mimo pozostawania we wspólnym gospodarstwie domowym, nie jest zaliczana do kategorii

14 Wyrok Sądu Najwyższego z dnia 20 maja 2008 roku, II UK 286/07, LEX nr 516822.

15 M. Skąpski, op. cit., s. 204.

16 Wyrok Sądu Najwyższego z dnia 2 lutego 1996 roku, II URN 56/95, OSNP 1996, nr 16, poz. 240 . 
osób współpracujących, ale ma status pracownika ${ }^{17}$. Przesłanka pozostawania we wspólnym gospodarstwie domowym może być rozpatrywana nie tylko w odniesieniu do małżeństwa, ale również do konkubinatu czy związków partnerskich.

\section{ZASADA RÓWNEGO TRAKTOWANIA ZATRUDNIONYCH W KONTEKŚCIE OSÓB WSPÓŁPRACUJĄCYCH}

Powstaje pytanie, czy pojęcie pozostawania we wspólnym gospodarstwie domowym jako kryterium rozróżnienia osoby współpracującej od pracownika jest dyskryminacją, naruszeniem zasady wyrażonej w art. 2a ustawy systemowej.

Zasada równego traktowania wyrażona w ustawie systemowej zakłada równe traktowanie wszystkich ubezpieczonych bez względu na płeć, rasę, pochodzenie etniczne, narodowość, stan cywilny czy stan rodzinny. Jak stwierdził Sąd Najwyższy w jednym z wyroków:

Istota zasady równości sprowadza się do tego, czy dopuszczalne jest różne traktowanie dwóch podmiotów w porównywalnej sytuacji ze względu na posiadanie przez jednego z nich pewnej cechy odróżniającej, która jest relewantna z punktu widzenia różnicowania. Relewantna, to znaczy taka, że jej wystąpienie stanowi uzasadniony powód innego traktowania posiadającego ją podmiotu ${ }^{18}$.

W ustawie systemowej mamy wyodrębnioną kategorię osób współpracujących, jednak najpierw osoba taka musi spełniać przesłanki, które są charakterystyczne dla pracownika, a dodatkowo jeżeli pozostaje we wspólnym gospodarstwie domowym, mimo że jest pracownikiem, staje się osobą współpracującą. Wyżej wymienione przesłanki nie mają zastosowania w sytuacji zatrudnienia młodocianych w rodzinnym zakładzie pracy w celu nauki zawodu. Posiadają oni status pracownika, mimo że pozostają we wspólnym gospodarstwie domowym. Status pracowniczy związany jest z rozszerzoną ochroną pracownika oraz z większa ilością przywilejów.

Podzielam stanowisko M. Skąpskiego, że nie jest uzasadnione wyłączenie z pracowniczego ubezpieczenia społecznego pewnej grupy osób tylko dlatego, że są członkami rodziny pracodawcy. W doktrynie takie wyłączenie jest krytykowane i niezrozumiałe. Toczy się dyskusja nad dalszym sensem istnienia wyżej wymienionej regulacji ${ }^{19}$.

Kategoria osób współpracujących pojawiła się w ustawie o ubezpieczeniu społecznym rzemieślników ${ }^{20}$. $\mathrm{Z}$ treści art. 1 tej ustawy wynikało, że obowiąz-

17 I. Jędrasik-Jankowska, Pojęcia i konstrukcje prawne ubezpieczenia społecznego, wyd. 3, Warszawa 2010, s. 54.

18 Wyrok Sądu Najwyższego z dnia 5 maja 2005 roku, III PK 14/05, OSNP 2005, nr 23, poz. 376.

19 M. Skąpski, op. cit., s. 213.

20 Ustawa z dnia 29 marca 1965 roku o ubezpieczeniu społecznym rzemieślników (Dz.U., nr 13, poz. 90). 
kowemu ubezpieczeniu społecznemu rzemieślników podlegali rzemieślnicy oraz osoby z nimi współpracujące. Za osoby współpracujące zostali uznani: małżonek, najbliżsi krewni i powinowaci rzemieślnika pracujący w jego zakładzie w wymiarze co najmniej połowy czasu pracy obowiązującego pracowników gospodarki uspołecznionej. Ustawa o ubezpieczeniu społecznym rzemieślników ustanowiła obowiązek ubezpieczenia społecznego osób prowadzących działalność gospodarczą $^{21}$. Podzielam pogląd wyrażony przez M. Skąpskiego, że w obecnym systemie prawnym uzasadnienie dla omawianej regulacji stanowi chęć objęcia ubezpieczeniem osób świadczących pracę, a nie podlegających ubezpieczeniu na żadnej innej podstawie. Niemniej kategoria osób współpracujących powinna mieć charakter pomocniczy wówczas, gdy nie ma innej podstawy ubezpieczenia ${ }^{22}$.

\section{RÓŻNICE POMIĘDZY PRACOWNIKAMI A KATEGORIĄ OSÓB WSPÓŁPRACUJĄCYCH}

Przeprowadzając analizę sytuacji pracownika i osoby współpracującej, warto zwrócić uwagę na odmienności występujące pomiędzy tymi dwoma tytułami ubezpieczenia. Osoba współpracująca jest objęta obowiązkiem ubezpieczeń społecznych $^{23} \mathrm{w}$ okresie od dnia rozpoczęcia współpracy przy prowadzeniu pozarolniczej działalności gospodarczej lub wykonywaniu umowy agencyjnej, lub umowy zlecenia, do dnia zakończenia tej współpracy, podczas gdy obowiązek ubezpieczeń społecznych po stronie pracownika powstaje w dniu nawiązania stosunku pracy, a wygasa w dniu ustania tego stosunku prawnego. Osoby współpracujące są objęte obowiązkiem ubezpieczeń społecznych w takim samym zakresie, jak osoba, z którą współpracują, to znaczy albo osobą prowadzącą pozarolniczą działalność, albo zleceniobiorcą. Płatnik składek osób współpracujących jest uzależniony od tego, z kim osoba współpracuje: czy ze zleceniobiorcą, czy z osobą prowadzącą pozarolniczą działalność gospodarczą. Dla osób współpracujących obowiązkowe są ubezpieczenia emerytalne, rentowe i wypadkowe, natomiast ubezpieczenie chorobowe jest dobrowolne. Pracownicy stanowią jedną z tych grup, która jest objęta pełnym obowiązkiem ubezpieczenia emerytalnego, rentowego, chorobowego i wypadkowego. W przypadku pracowników przychody z tytułu zatrudnienia w ramach stosunku pracy stanowią podstawę wymiaru składek. Co do zasady podstawę wymiaru składki na ubezpieczenie społeczne osoby współpracującej z osobą prowadzącą pozarolniczą działalność stanowi zadeklarowana przez nią kwota, która nie może być niższa od kwoty równej $60 \%$ prognozowanego prze-

21 M. Skąpski, op. cit., s. 209-210.

22 Ibidem, s. 213.

${ }^{23}$ Od następujących ryzyk: emerytalnego, rentowego, wypadkowego - ubezpieczenie chorobowe jest dla osoby współpracującej dobrowolne. 
ciętnego miesięcznego wynagrodzenia w danym roku kalendarzowym. Pracownik spełniający przesłanki zakwalifikowania go do grupy osób współpracujących uzyskuje status osoby współpracującej, jednak nie dotyczy to pracownika, który świadczy pracę na podstawie umowy o pracę w celu przygotowania zawodowego.

\section{ZAKOŃCZENIE}

De lege lata brak uzasadnienia dla wyodrębnienia kategorii ubezpieczonych, jaką stanowią osoby współpracujące. Nie ma podstaw do wyłączenia z grupy pracowników kategorii osób współpracujących tylko na tej podstawie, że są członkami rodziny i pozostają we wspólnym gospodarstwie domowym ${ }^{24}$.

De lege ferenda instytucja osoby współpracującej powinna mieć charakter pomocniczy i znajdować zastosowanie do członków rodziny pracodawcy wtedy, gdy nie mają innej podstawy ubezpieczenia społecznego. W szczególności dotyczyłoby to osób, które świadczą pracę w ramach pomocy rodzinnej bez umowy ${ }^{25}$. Pogląd ten został wyrażony już w 2000 roku przez M. Skąpskiego, jednak nadal przepisy prawa w tym zakresie nie zostały znowelizowane.

W polskim systemie prawnym, a dokładnie w polskim kodeksie pracy, nie zostało uregulowane zatrudnienie członków rodziny. Niemniej komisja kodyfikacyjna dostrzegła potrzebę nowelizacji prawa pracy i rozpoczęła pracę nad tym zagadnieniem. W efekcie w 2008 roku powstał projekt kodeksu pracy ${ }^{26}$, w którym księga 6 została zatytułowana „Nietypowe stosunki pracy” i zawierała tytuł siódmy poświęcony pracownikom rodzinnym. Powyższy projekt wprowadził pojęcie pracownika rodzinnego, za którego została uznana osoba zatrudniona w zakładzie pracy, w którym wszyscy pracownicy są członkami rodziny pracodawcy ${ }^{27}$. Za członków rodziny uznano małżonka i rodziców pracodawcy, a także jego dzieci - własne i przysposobione, dzieci jego małżonka, dzieci przyjęte na wychowanie i utrzymanie $w$ ramach rodziny zastępczej, wnuki, rodzeństwo i ich małżonków ${ }^{28}$. Niestety, proponowane przez komisję kodyfikacyjną rozwiązania

24 M. Skąpski, op. cit., s. 213.

25 Ibidem.

26 Projekt indywidualnego i zbiorowego Kodeksu pracy przygotowany przez Komisję Kodyfikacyjną Prawa Pracy w 2008 roku, powołaną rozporządzeniem Rady Ministrów z dnia 20 sierpnia 2002 roku w sprawie utworzenia, organizacji i trybu działania Komisji Kodyfikacyjnej Prawa Pracy (Dz.U. 139, poz. 1167).

27 Art. 449 projektu do Kodeksu pracy z 2008 roku: „§ 1. Pracownikiem rodzinnym jest pracownik zatrudniony w zakładzie pracy, w którym wszyscy pracownicy są członkami rodziny pracodawcy. § 2. Za członków rodziny, o których mowa w § 1, uważa się: małżonka i rodziców pracodawcy, a także jego dzieci - własne i przysposobione, dzieci jego małżonka, dzieci przyjęte na wychowanie i utrzymanie w ramach rodziny zastępczej, wnuki, rodzeństwo i ich małżonków”.

28 Art. 449 § 2 projektu do Kodeksu pracy z 2008 roku: „Za członków rodziny, o których mowa w $\S 1$, uważa się: małżonka i rodziców pracodawcy, a także jego dzieci - własne i przy- 
prawne nie zostały wprowadzone do polskiego systemu prawnego. Uważam, że unormowanie zagadnienia zatrudnienia pracowników rodzinnych jest koniecznością, gdyż wprowadzi to przejrzystość w przepisach prawnych. Niektóre państwa Unii Europejskiej skodyfikowały zatrudnienie członków rodziny - przykład może stanowić włoski kodeks cywilny, w którym została uregulowana omawiana instytucja.

\section{BIBLIOGRAFIA}

Jędrasik-Jankowska I., Geneza, rozwój i stan ubezpieczenia społecznego w Polsce, [w:] Ubezpieczenia społeczne w procesie zmian 80 lat Zakładu Ubezpieczeń Społecznych, pod red. K.W. Frieske, E. Przychodaj, Warszawa 2014.

Jędrasik-Jankowska I., Pojęcia i konstrukcje prawne ubezpieczenia społecznego, wyd. 3, Warszawa 2010. Jończyk J., Prawo zabezpieczenia społecznego, wyd. 3 uaktualnione, Kraków 2006.

Kostrzewa P., [w:] E. Dziubińska-Lechnio, J. Kaleta, M. Kostrzewa, E. Kowalczyk, E. Skowrońska, A. Ślązak, Ubezpieczenia spoleczne, Warszawa 2014.

Kostrzewa P., Komentarz do art. 2(a) ustawy o systemie ubezpieczeń społecznych, System Informacji Prawnej LEX 2014 (stan prawny: 01.01.2014).

Postanowienie Sądu Najwyższego z dnia 8 lutego 2006 roku, III UZP 3/05, LEX nr 177435.

Skąpski M., Zagadnienia stosunku pracy między członkami rodziny, Warszawa 2000.

Ustawa z dnia 29 marca 1965 roku o ubezpieczeniu społecznym rzemieślników (Dz.U., nr 13, poz. 90).

Ustawa z dnia 13 października 1998 roku o systemie ubezpieczeń społecznych (t.j. Dz.U. z 2015 roku, poz. 121).

Wyrok Sądu Najwyższego z dnia 2 lutego 1996 roku, II URN 56/95, OSNP 1996, nr 16, poz. 240.

Wyrok Sądu Najwyższego z dnia 5 maja 2005 roku, III PK 14/05, OSNP 2005, nr 23, poz. 376.

Wyrok Sądu Najwyższego z dnia 20 maja 2008 roku, II UK 286/07, LEX nr 516822.

Wyrok Trybunału Konstytucyjnego z dnia 12 września 2000 roku, K 1/00, OTK 2000, poz. 185.

\section{SUMMARY}

Employed family members do not constitute a category of persons assisting as employees. They constitute a separate category of insured persons as assisting persons. In order to qualify for this category of insured persons, they must meet several prerequisites. First of all, basic qualifying criteria for a group of employees must be met. Such persons must also remain in the same household as a person conducting non-agricultural business. This prerequisite is not very well specified and raises a lot of controversy, it will be individually considered in each case. It does not apply to minors signing an employment contract for vocational training as in such a situation, the minor has the status of an employee and not an assisting person. Therefore, the employment of family members is not of a uniform nature and is subject to separate regulations.

Keywords: insurance entities; title insurance; employee; collaborator; cooperation in conducting an economic activity; staying in the same household

sposobione, dzieci jego małżonka, dzieci przyjęte na wychowanie i utrzymanie w ramach rodziny zastępczej, wnuki, rodzeństwo i ich małżonków”. 